\title{
Maatalouskoneiden työturvallisuusriskit ja niiden hallinta
}

\author{
Jarkko Leppälä ${ }^{1)}$, Matts Nysand ${ }^{2)}$, Ari Ronkainen ${ }^{2)}$, Katja Kauppi ${ }^{1)}$ ja Risto Rautiainen ${ }^{3)}$ \\ ${ }^{1)}$ Luonnonvarakeskus, Luke, Latokartanonkaari 9, 00790 Helsinki, etunimi.sukunimi@luke.fi \\ ${ }^{2)}$ Luonnonvarakeskus, Luke, Vakolantie 55,07900 Vihti, etunimi.sukunimi@luke.fi \\ ${ }^{3)}$ Luonnonvarakeskus, Luke/The University of Nebraska, College of Public Health, Omaha, \\ Nebraska 68105, USA, rrautiainen@unmc.edu
}

\section{Tiivistelmä}

Luonnonvarakeskuksen hallinnoimassa Koneturva - hankkeessa tavoitteena on vähentää maatalouskoneiden aiheuttamia tapaturmia sekä edistää maataloustyön turvallisuutta ja riskienhallintaa. Maatalouskonetapaturmien suhteellinen osuus kaikista maatalouden tapaturmista on kasvanut. Lisäksi suuri osa maatalouden konetapaturmista on ns. vakavia tapaturmia, joiden keskimääräinen sairasloma-aika on yli 32 työpäivää. Tämän vuoksi maatalouskoneiden tapaturmariskien hallintaan on panostettava entistä voimakkaammin. Luonnonvarakeskus Luke:n hallinnoimassa Koneturva - hankkeessa tutkitaan maatalouskoneiden tapaturmariskejä ja kehitetään riskien hallintakeinoja.

Hankkeessa tehtiin kattava tilastokatsaus Maatalousyrittäjien eläkelaitoksen (Mela) tilastoista maatalouskonetapaturmista Suomessa kymmenen viime vuoden ajalta sekä järjestettiin koneturvallisuuskysely maatalouskoneiden käyttäjille. Tilastojen ja kyselyn tulosten perusteella valikoitiin tärkeimmät koneryhmät, joiden työturvallisuusriskien hallintaan tulisi eniten panostaa tällä hetkellä. Hankkeessa koottiin valikoitujen koneryhmien riskienhallintakeinoja kirjallisuuden, konestandardien, käyttöohjeiden ja viljelijähaastattelujen avulla.

Hankkeen konetapaturmien tilastokatsauksen tulosten perusteella hankkeen riskienhallintakeinojen tarkastelu rajattiin maatalouden peltotyökoneisiin. Tapaturmataajuuden ja merkittävyyden perusteella tarkasteltaviksi koneryhmiksi valittiin traktorit, puimurit, kippiperävaunut, kuormaimet, äkeet ja pellonmuokkauskoneet sekä lannoittimet ja kylvökoneet. Lisäksi tarkastellaan yleisesti ottaen peltotyökoneiden automaatiojärjestelmiä. Maatalouskoneiden automaatiojärjestelmät ovat yleistyneet maatiloilla, joten niihin liittyvää työturvallisuutta ja riskienhallintaa on syytä tutkia. Yli 30 prosenttia kyselyyn vastanneista maatalouskoneiden käyttäjistä piti koneiden automaatiojärjestelmiä vaikeina. Yleisesti ottaen maatalouskoneita pidetään turvallisina ja koneiden käyttöohjeet olivat ymmärrettäviä noin 74 prosentin vastaajan mielestä. Käyttöohjeiden lisäksi koneiden käyttöönotto-opastusta ja koneiden huollon helpottamista pidettiin tärkeinä työturvallisuusriskien hallintakeinoina. Yli kolmannes maatalouden konetapaturmista on tapahtunut koneiden huoltotehtävissä kymmenen viime vuoden aikana. Merkittävä tekijä konetapaturmien ehkäisyssä on maatilan turvallisuuskulttuuri ja koneiden käyttäjien toimintatavat. Hankkeen tuloksena julkaistaan koneturvallisuusopas vuonna 2016. Hankkeen rahoittajia ovat Mela, Maatalouskoneiden Tutkimussäätiö ja Luonnonvarakeskus.

Asiasanat: maatalous, maatalouskone, työturvallisuus, tapaturma, riskienhallinta

\section{Johdanto}

Maatalouden konetapaturmat aiheuttavat ison osan ns. vakavista eli yli 30 päivän sairasloman aiheuttavista työtapaturmista maataloudessa. Vuosittain konetapaturmia tapahtuu maataloudessa keskimäärin 1 000-1 200 tapausta, mikä on noin 20 - $25 \%$ maatalousyrittäjien tapaturmista (Leppälä ym. 2014; Eskola 2012). Tapaturmien lisäksi esimerkiksi väärät työtavat maatalouskoneiden käytössä voivat altistaa työperäisille ammattitaudeille kuten tuki - ja liikuntaelinten (TULE) sairauksille (Mayton ym. 2007). Näihin sairauksiin altistavia työtehtäviä on maatalouskonetöissä mm. yksipuolinen työliike, voimaa vaativat käden vääntö- ja kiertoliikkeet, teräväkulmaiset työkalut, epäsopiva työvälineiden mitoitus ja muoto, työvälineen tärinä tai tärähtely, työskentely kylmässä tai vedossa, hankalat työasennot, kumara-kiertynyt työasento, traktorilla ajaminen ja työntekijän yksilölliset sairaudelle altistavat tekijät (TTL 2013). Maatalouskoneiden tapaturmien ja ammattitautien vaikutuksista, käyttöympäristöön liittyvistä riskeistä eri konetyypeissä ja koneiden käytön 
turvallisuusriskien hallintakeinoista tarvitaan lisätutkimusta. Koneturva-hanketta rahoittavat Maatalousyrittäjien eläkelaitos (Mela), Maatalouskoneiden Tutkimussäätiö ja Luonnonvarakeskus (Luke).

Koneiden turvallisuuden hallinta voidaan jakaa kahteen osaan: koneen valmistajan velvollisuuksiin koneen suunnitteluvaiheessa ja työnantajan velvollisuuksiin käyttövaiheessa. Kone on suunniteltava siten, että koneen käyttäjän turvallisuus ei vaarannu koneen tarkoitetun käytön ja kohtuudella ennakoitavissa olevan väärinkäytön aikana. EU:n konedirektiivissä annetaan määräyksiä koneiden turvallistamisesta. Konedirektiivi on saatettu Suomessa voimaan Valtioneuvoston asetuksella (Vna 400/2008; 2006/42/EY). Kun kone suunnitellaan sitä koskevan yhdenmukaistetun standardin mukaisesti, voidaan olettaa koneen olevan vaatimusten mukainen konedirektiivin suhteen niiden riskien osalta, jotka standardi kattaa. Tutkimusten mukaan vuonna 2005 konevalmistajista 100 $\%$ oli sitä mieltä, että turvallisuusstandardit selkiyttivät täysin tai osittain turvallisuusvaatimuksia, lisäsivät asiakkaan luottamusta 94\%:n mielestä ja vahvistivat yrityksen kilpailukykyä 79 \%:n mielestä (Teye ym. 2004).

Maatalouskoneiden turvallisuuden hallinnassa tulee huomioida, että koneita käyttävät myös ammattiviljelijän lisäksi myös tämän perheenjäsenet, palkkatyövoima, lomittajat ja muu satunnainen aputyövoima. Koneen käyttövaiheessa työnantajan ja tässä tapauksessa maatalousyrittäjän tulisi huolehtia koneiden turvallisesta käytöstä ja huollosta. (Suutarinen ym. 1998; Suutarinen 1996). Jos maatalousyrittäjän ja aputyövoiman välillä on palkkatyösuhde tai sitä vastaava opinto - tai muu työsuhde, on viljelijän huolehdittava työturvallisuuslain (Laki 738/2002) ja valtioneuvoston antaman koneiden käyttöä koskevan asetuksen (Vna 403/2008) määräysten täyttymisestä. Niitä ovat mm. koneen valitsemiseen ja sijoittamiseen, koneen käyttöohjeisiin, koneen toimintakunnon varmistamiseen sekä koneen vaaran arviointiin ja sen poistamiseen liittyvät määräykset. (Leppälä ym. 2013; SFS 2010). Uusi automaatioteknologia maataloudessa vaatii myös uutta osaamista sekä maatalouskoneiden käyttäjiltä ja maatalouden työnantajilta turvallisuustekijöiden ohjeistamiseen (Malm ym. 2013). Teollisuusautomaation puolelta tiedetään, että automaatiojärjestelmien vikaantuminen on syynä vain pieneen osaan onnettomuuksista. Valtaosa automaatiojärjestelmien onnettomuuksista liittyy koneen odottamattomaan käynnistymiseen tai arvaamattomaan toimintaan, joihin liittyviä riskejä voidaan pienentää myös parantamalla käyttäjän ymmärrystä järjestelmän toiminnasta sekä nostamalla hänen tilannetietoisuuttaan järjestelmän tilasta. Samanlaista kehitystä voidaan odottaa tapahtuvan maatalouskoneissa järjestelmien automaatioasteen kasvaessa. (Malm ym. 2013, Ronkainen 2013, Ronkainen 2011; Ronkainen 2010). Toiminnan ja koneiden muuttuessa maatalouskoneiden käyttäjät tulevat tarvitsemaan tehostetusti ohjeistusta koneiden käytön turvallisuustekijöiden tunnistamiseen ja turvallisuustekijöiden perehdyttämiseen muille käyttäjille.

\section{Tavoite}

Luonnonvarakeskuksen Koneturva - hankkeessa tavoitteena on vähentää maataloudessa tapahtuvia konetapaturmia ja vakavien tapaturmien riskiä. Tutkimuksessa selvitettiin, mitkä ovat maataloudessa käytössä olevien koneiden tärkeimmät turvallisuusriskitekijät, riskien suuruus ja niiden hallintakeinot. Hankkeessa tuotetaan maatalousyrittäjille opas maatalouskoneiden turvallisuusriskeistä ja riskienhallinnan keinoista sekä tarkastellaan maatalouden konetapaturmien ja konetapaturmakustannusten kehitystä Suomessa.

\section{Aineisto ja menetelmät}

Hankkeessa tehtiin yksityiskohtainen maatalouden konetapaturmia koskeva aineistohaku Melan tapaturmatilastosta. Konetapaturmista analysoitiin eri konetyyppien aiheuttamat henkilövahingot ja kustannusluokat. Tilastohaussa mukana olleet tapaturmamuuttujat olivat tapahtuma-aika, maksetut korvaukset, päivärahajakso, ikä, sukupuoli, syntymävuosi, aiheuttaja, työvaihe, vahinkotyyppi, työliikkeet, vamman/taudin laji, yritystoiminnan alkamisvuosi, laitteen kuvailu ja vahingon kuvailu. Konetapaturmien yleiset tilastomuuttujat koottiin omaksi taulukokseen ja data jaettiin tämän jälkeen tärkeimpiin konelajeihin, joissa oli sattunut eniten tapaturmia ja joilla oli tapahtunut erityisen vakavia tapaturmia.

Koneisiin liittyviä turvallisuus- ja käyttökokemuksia kerättiin viljelijöiltä KoneAgriamessujen yhteydessä järjestetyssä kyselyssä (N=204) vuonna 2014. Kyselyn kysymykset jakaantuivat 
maatilaa koskeviin taustakysymyksiin, koneturvallisuutta koskeviin kokemuksiin, käyttöohjeisiin, automaatiojärjestelmiin ja koneiden käytettävyyteen liittyviin kysymyksiin. Kyselyn jälkeen tehtiin maatiloilla case - yrittäjähaastatteluja $(\mathrm{N}=15)$, joiden avulla pyrittiin selvittämään tarkemmin tilastojen mukaan vaarallisimpien konelajien ja maatalouskoneiden automaation turvallisuuteen liittyviä pullonkauloja ja haasteita. Hankkeessa tehtiin myös käyttöohjeiden turvallisuusohjeistukseen liittyvää vertailua. Eri maatalouskonelajien turvallisuustekijöitä, riskejä ja riskienhallintaa määritetään hankkeen lopuksi aineistovertailun avulla. Tämä artikkeli koskee lähinnä tilastoaineistoa ja maatalouskoneiden käyttäjille tehdyn kyselyn tuloksia.

\section{Tulokset}

Tilastotarkastelu

Melan tapaturmatilastoista tehtiin aineistohaku maatalouskonetapaturmista vuosilta 2004-2013. Aineistossa on yhteensä 10528 konetapaturmaa. Konetapaturmista analysoitiin eri konetyyppien aiheuttamat henkilövahingot ja keskimääräinen korvaus per tapaturma. Yleisesti ottaen maatalouden tapaturmien määrä on vähentynyt Suomessa viimeisen kymmenen vuoden aikana 6000 tapaturmasta vähän yli 4000 tapaturmaan vuodessa. Sen sijaan tapaturmat, joissa maatalouskone on merkitty tapaturman aiheuttajaksi, eivät ole lukumäärältään vähentyneet vaan pysynyt noin tuhannessa tapaturmassa per vuosi. Maatalouskoneilla tapahtuvien tapaturmien osuus maatalouden tapaturmista on siten kasvanut viisi prosenttia kymmenen vuoden aikana. Maatalouskonetapaturmat ovat usein vakavia. Maatalouskonetapaturmista aiheutuu usein ns. vakava eli yli 30 päivän sairasloman aiheuttava tapaturma. Konetapaturmista maatalousyrittäjille aiheutuvien työkyvyttömyysjaksojen keskimääräinen pituus on 32,5 päivää. Keskimääräinen korvaus per maatalouden konetapaturma on noin 3800 euroa. Yleisesti ottaen maatalouden tapaturmat ovat Suomessa vähentyneet tilojen vähentyessä, mutta konetapaturmat eivät ole vähentyneet samassa suhteessa. Kymmenen vuoden aikana vuosina 2004 - 2013 traktorit ovat ylivoimaisesti suurin tapaturmien aiheuttaja (2281 tapaturmaa), sen jälkeen sahat ja klapikoneet (884 kpl), porat, höylät yms. $(817 \mathrm{kpl})$, perävaunut (754 $\mathrm{kpl})$, leikkuupuimurit $(515 \mathrm{kpl})$, kuormaimet $(478 \mathrm{kpl})$, eläinten ruokinta- ja lantakoneet $(369 \mathrm{kpl})$ sekä erilaiset peltotyökoneet 200-300/koneryhmä (Kuva 1).

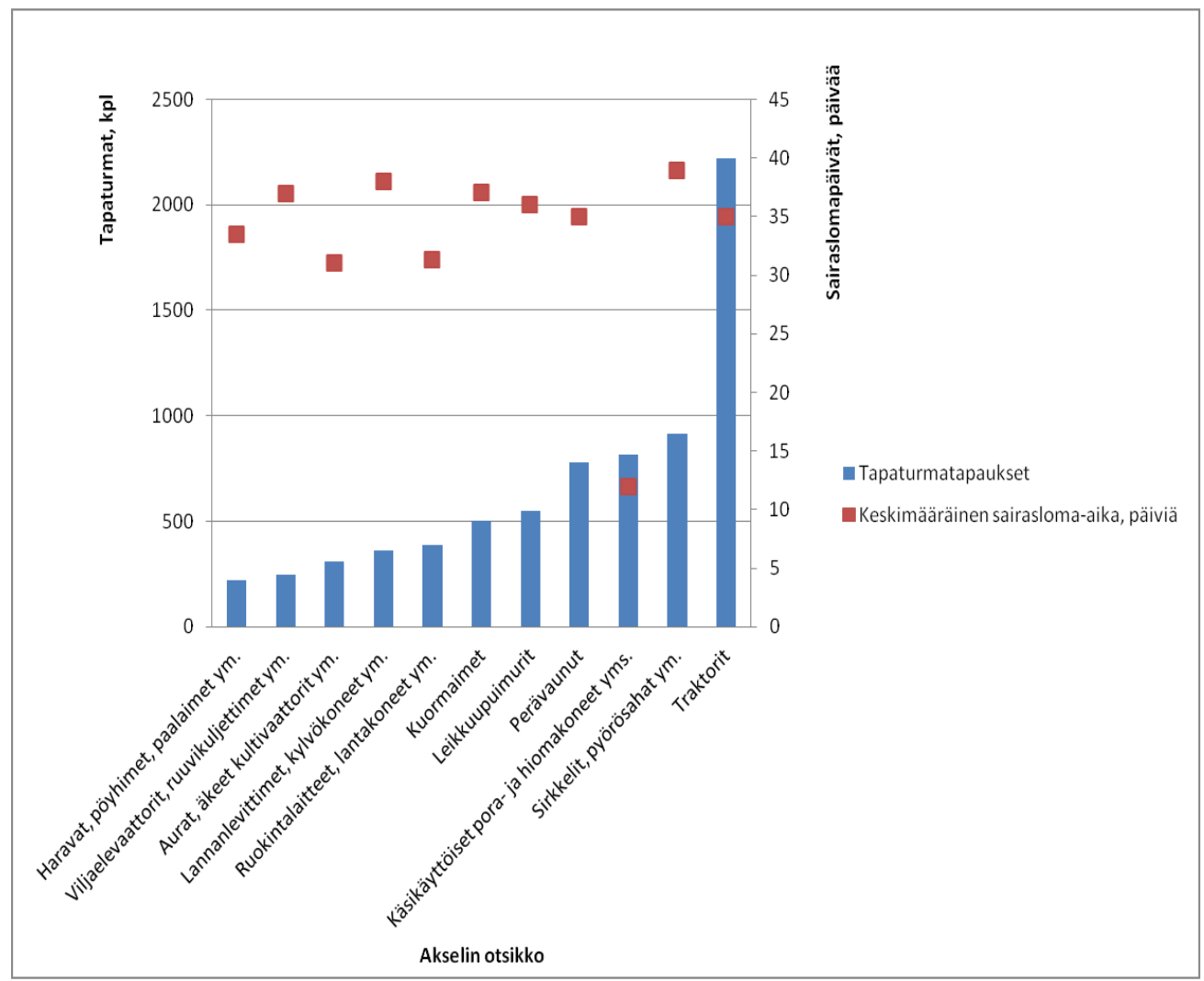

Kuva 1. Tapaturmat ja keskimääräiset sairasloma-ajat eri maatalouskoneilla vuosina 2004-2013. 
Kotieläintuotannossa ruokintalaitteiden ja lantakoneiden tapaturmat olivat keskimäärin kustannuksiltaan suurimpia (lähes 6000 euroa/tapaturma). Traktoritapaturmien keskimääräinen tapaturmien korvaus oli 3866 euroa. Traktoritapaturmissa oli kuitenkin paljon hajontaa kuten esimerkiksi liikkuvan traktorin tapaturmat ovat vakavampia ja kalliimpia kuin hallintalaitteiden tapaturmat. Muista maatalouden työkoneista kuormainten kanssa tapahtuvat tapaturmat olivat keskimäärin seuraavaksi kalleimpia (4985 euroa/tapaturma). Lannanlevitinten ja kylvökoneiden kanssa tapahtuneet tapaturmakustannukset olivat keskimäärin 4700 euroa, auroihin ja äkeiden käyttöön liittyvät tapaturmat 4356 euroa ja leikkuupuimurit aiheuttajina 4053 euroa (Kuva 2). On huomioitavaa, että lähes kaikilla maatalouskoneilla tapaturmien keskimääräiset kustannukset ovat melko suuria, mistä voi päätellä niihin liittyvät tapaturmat ovat usein vakavia.

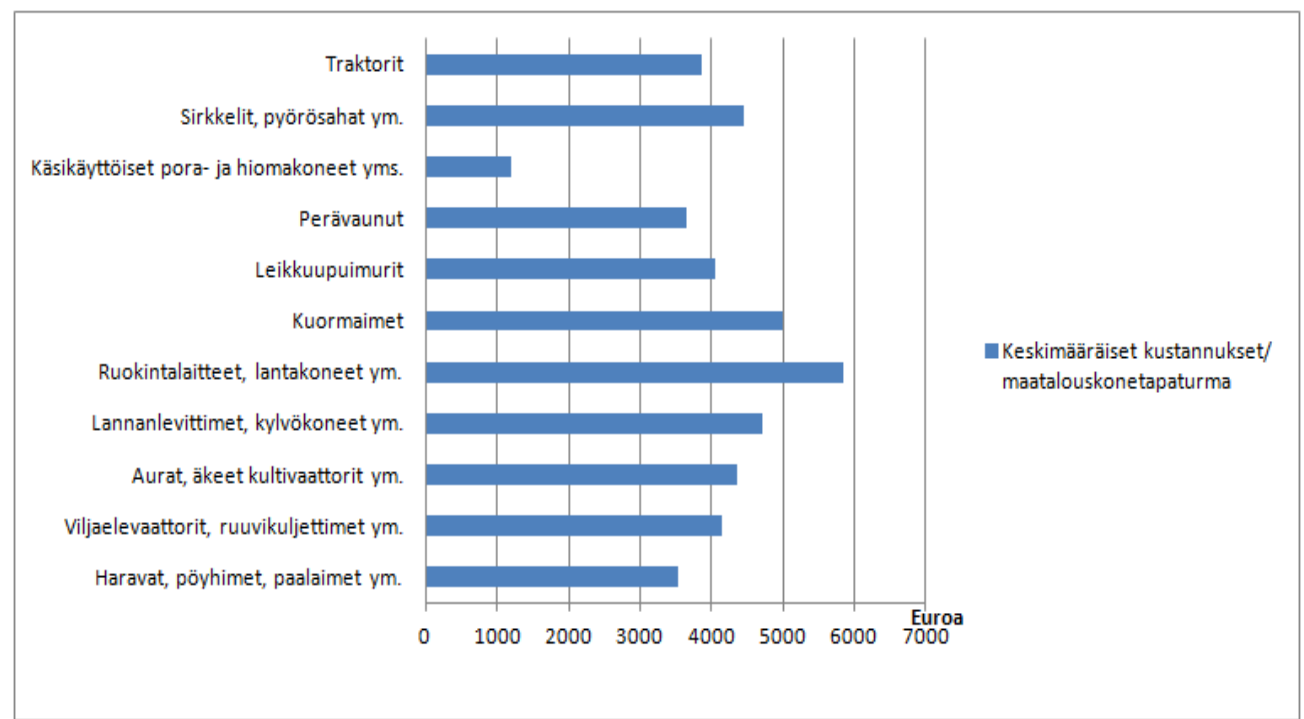

Kuva 2. Keskimääräiset tapaturmien korvauskustannukset tapaturmaa kohti eri maatalouskoneilla.

Työvaiheista eniten konetapaturmia tapahtuu koneiden korjauksessa, kokoamisessa tai valmistuksessa (32\%). Onnettomuuksia sattuu viljely-, muokkaus- tai ruiskutustöissä 14 prosenttia, eläinten hoitotöiden koneiden käytössä 11 prosenttia, viljan ja sadon varastonnissa 8,5 prosenttia, työkoneiden siirroissa ja kytkemisessä 5,1 prosenttia, infrastruktuurin ylläpidossa 5,1 prosenttia ja heinä- ja nurmirehutyövaiheissa neljä prosenttia. Naisia maatalousyrittäjistä on $33 \%$, mutta kuitenkin naisille tapahtuu vain kahdeksan prosenttia konetapaturmista. Ajankohdista yleisimmät tapaturmaajankohdat ovat keväällä ja syksyllä maatalouden sesonkiaikoina, viikonpäivistä maanantait sekä keskipäivällä kello 12 sekä kello 14 .

Kysely ja käyttökokemukset

Viljelijöiden käyttökokemuksia maatalouskoneista ja koneiden turvallisuudesta kerättiin kyselyssä KoneAgrian maatalouskonenäyttelyssä ja MTT:n uutiskirjeessä vuonna 2014 syksyllä. Vastauksia kyselyyn saatiin yhteensä 204. Vastaajista $63 \%$ oli kasvintuotantotilojen ja $30 \%$ eläintuotantotilojen yrittäjiä. Vastaajista miehiä oli $88 \%$ ja keski-ikä 46 vuotta. Vastaajien tilakoon keski-arvo oli 74,5 hehtaaria. Vastaajista $22 \%$ :lla oli tilalla käytössä palkkatyövoimaa. Noin $42 \%$ vastaajista ilmoitti tilalla tapahtuneesta tapaturmasta tai läheltä piti - tilanteesta. Vaara-tilanteen kokeneista maatalouskoneiden käyttäjistä $25 \%$ oli myös loukkaantunut tilanteessa.

Vastaajilta kysyttiin, millä tavoin maatalouden koneturvallisuutta voitaisiin parhaiten parantaa. Kysymykseen vastasi 196 maatalouskoneiden käyttäjää. Eniten kannatusta koneturvallisuuden parantamiseksi maataloudessa sai koneen ostajalle tehtävä käyttöönotto-opastus (56 \% vastaajista, Kuva 3). Käyttöönotto-opastukseen liittyen $20 \%$ vastaajista ilmoitti, että käyttöönotto-opastus koneen oston yhteydessä ei ollut riittävää (Kuva 4). Seuraavaksi eniten koneturvallisuutta parantaisi käyttäjien mukaan koneiden huollon helpottaminen (48 \%). Lähes $40 \%$ vastaajista ilmoitti, että koneiden huoltaminen ei välttämättä ole turvallista ja helppoa. Lisäksi maatiloilla tulisi huomioida koneiden käyttöopastukset kaikille, jotka koneita käyttävät tilalla. Tiloilla 
voi olla perheenjäseniä ja väliaikaista työvoimaa, joille tulee antaa tarvittava käyttöopastus. Yhtä tärkeä koneturvallisuuden kehittämiskeino oli vastaajien mukaan käyttäjille itselleen tehtävä turvallisuuteen liittyvä asennekasvatus (45\% vastaajista). Koneiden käyttäjät ovat mahdollisesti havainneet omassa työssään tai vaaratilanteiden jälkeen, että turvallisuus oli jonkin työtehtävän yhteydessä puutteellinen tai oli kiireessä unohdettu.

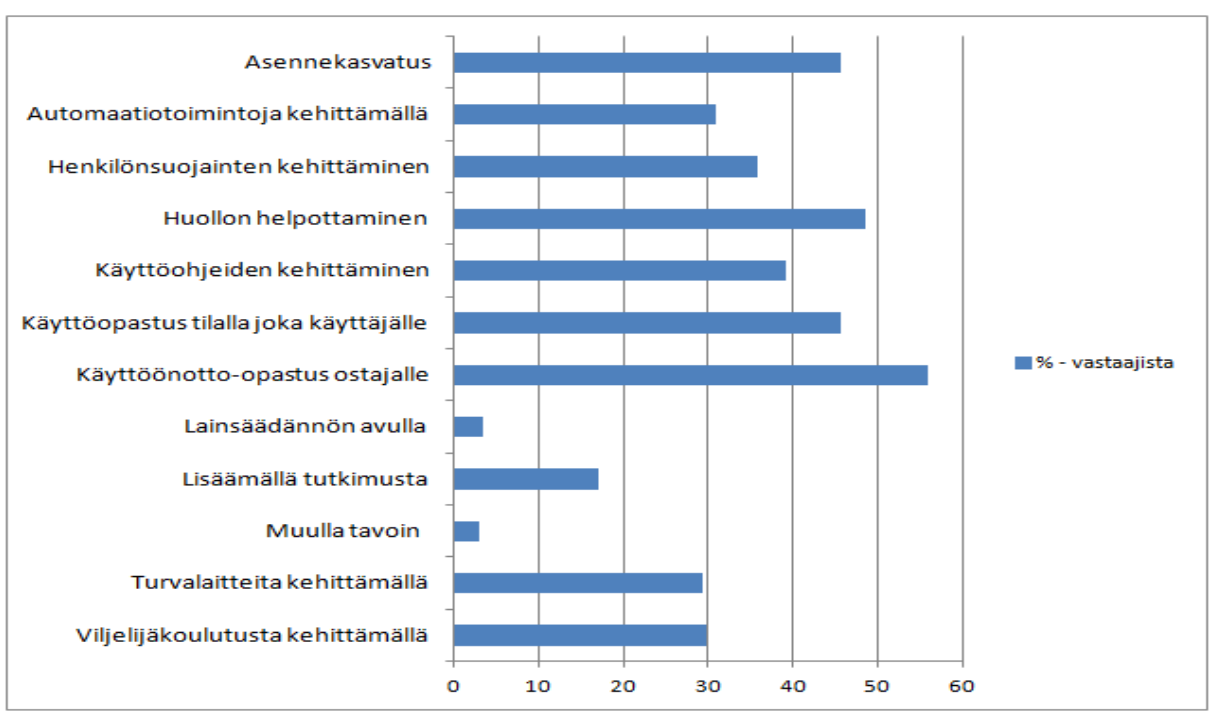

Kuva 3. Maatalouden koneturvallisuuskyselyn vastausjakauma koneturvallisuuden tärkeimmistä kehittämiskeinoista

Käyttöohjeiden ymmärrettävyyttä parantaisi $25 \%$ vastaajista (Kuva 4). Turvallisuusohjeiden ymmärrettävyyden ja käytettävyyden kehittämistä kannatti $17 \%$ vastaajista. Koneiden käyttöohjeiden ymmärrettävyyttä ja laatua yleensä sekä määräystenmukaisuutta selvitettiin myös lukemalla otos markkinoilla olevien koneiden käyttöohjeista. Luettaviksi valittiin hankkeessa tarkasteltavien työkonetyyppien eli kippiperäkärryjen, maanmuokkauskoneiden, kylvökoneiden ja puimureiden käyttöohjeita, yleensä kolme per konetyyppi. Konemerkit ja -mallit valittiin sattumanvaraisesti. Tarkastelu osoitti että käyttöohjeiden ymmärrettävyydessä ja laadussa yleensä on melko usein parantamista, mikä osaltaan tukee käyttäjäkyselyn vastaajien mielipidettä. Puutteellisesti tai vaikeatajuisesti esitetyt asiat voitaisiin parantaa muuttamalla asioiden ilmaisutapoja ja jäsentelyä sekä joissakin tapauksissa lisäämällä ja tarkentamalla kuvitusta. Ulkomaisten koneiden ohjeissa on joskus huonoja käännöksiä alkuperäiskielisistä ohjeista. Ohjeiden käytettävyys paranee myös, kun täydellisen käyttöohjeen lisäksi toimitetaan hyvin lyhyt, tiivistetty pikaohje joka on helppo pitää mukana traktorissa tai koneessa. Hankkeessa ei voitu selvittää minkä verran valmistajat ovat luetuttaneet käyttöohjeita esimerkiksi konekäyttäjillä ja ulkopuolisilla asiantuntijoilla ennen markkinoille laskemista, mutta sellainen luetuttaminen olisi eräs keino käyttöohjeiden ymmärrettävyyden yleensä laadun parantamiseen.

Maatalouskoneissa on yhä enemmän automaatiolla toimivia järjestelmiä. Tutkimuksessa on saatu tunnistettua muutamia automaatiojärjestelmien ongelmia ja niiden riskejä, joihin viljelijä voi itse vaikuttaa. Maatalouskoneiden automaatiojärjestelmiin liittyviä vaaratilanteita oli tapahtunut noin $22 \%$ kaikista vaaratilanteista (yht. $21 \mathrm{kpl}$ ) eli noin $10 \%$ vastaajista. Automaatioon liittyvissä vaaratilanteista joka neljäs vaaratilanne oli johtanut koneen käyttäjän loukkaantumiseen. Maataloustuotannon automaation vaaratilanteiden tutkimuksessa on tähän asti jouduttu turvautumaan onnettomuuskuvauksiin ja muiden teollisuudenalojen huomioihin. Kyselyn ja tapahtuma kuvausten perusteella esiin nousee kaksi suurta vikaantumisten ja vaaratilanteiden aiheuttajaa. Ensimmäisenä esiin nousee automaatiojärjestelmän asennuksesta, sähkönsyötöstä ja suojausten heikkoudesta (mekaaninen ja sähkömagneettinen) johtuvat häiriöt, joidenka takia käyttäjät joutuvat tekemään poikkeus ratkaisuja, jotka voivat johtaa vaaratilanteisiin $(40 \%)$. Toisena vaaran aiheuttajana oli koneiden yllättävä toiminta, joka voi johtua toiminnon suunnitteluvirheestä tai käyttäjän väärästä käsityksestä koneen toiminnassa (24 \%). Tämä löydös oli samansuuntainen muiden teollisuuden alojen havaintojen kanssa. 


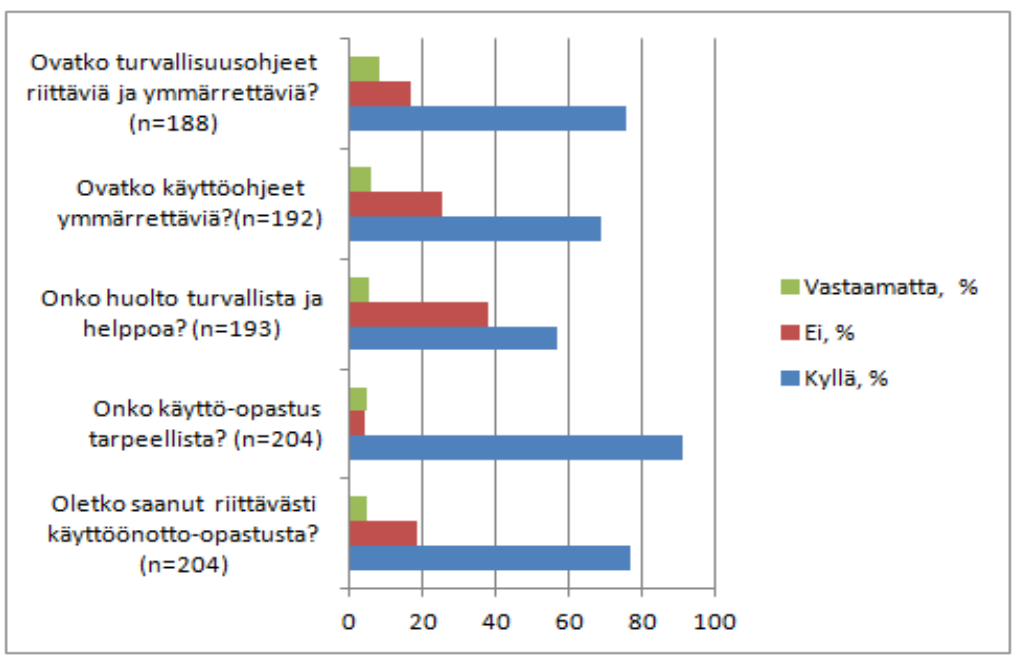

Kuva 4. Maatalouden koneturvallisuuskyselyn vastausjakauma käyttöohjeiden ymmärrettävyyteen, huollon turvallisuuteen ja käyttöopastukseen liittyen.

Konelajikohtaiset tapaturmatarkastelut esimerkkinä leikkuupuimuri

Peltotyökoneiden käytössä sattuu lukumääräisesti eniten tapaturmia maatalouden töissä. Jokaisesta peltotyökoneesta tehdään oma tilastokatsaus ja riskienhallinnan tarkastelu valmisteilla olevaan koneturvallisuusoppaaseen. Esimerkiksi Koneturva - hankkeeseen liittyvässä Helsingin yliopiston pro gradu - tutkimuksessa on tutkittu leikkuupuimurin käytön yhteydessä tapahtuvia tapaturmia. Leikkuupuimuritapaturmissa loukkaantuneiden keski-ikä oli 48,9 vuotta ja onnettomuudet aiheuttivat keskimäärin 36,1 päivän työkyvyttömyyden. Suurin yksittäinen työvaihe, joka aiheutti yli 38 prosenttia kaikista tapaturmista, oli koneen korjaukseen ja huoltoon liittyvät tehtävät. Lisäksi tapaturmia aiheuttivat puimurin askelmat (yli $16 \%$ ), sekä yli 12 prosentilla tukoksen poistoon ja koneen puhdistukseen liittyvät tehtävät.

Yli $42 \%$ loukkaantuneista loukkasi leikkuupuimuritapaturmassa sormensa. Tapaturmista aiheutui yli $40 \%$ avohaavoja ja yli 12 prosentille nyrjähdyksiä ja venähdyksiä sekä pinnallisia vammoja. Kymmenen viime vuoden aikana Suomessa sattui kaksi kuolemaan johtanutta leikkuupuimuritapaturmaa. Yleisesti leikkuupuimuritapaturmat sattuivat elo- ja syyskuun aikana ja todennäköisimmin torstaisin kello 14. Tilakäynneillä havaittuja rakenteellisia puutteita leikkuupuimuritarkastelussa olivat liian korkeat askelvälit portaissa, askelmien puuttuminen viljasäiliöstä, hankalissa paikoissa sijaitsevat huoltokohteet ja ensiapulaukun puuttuminen puimurista.

\section{Tulosten tarkastelu ja johtopäätökset}

Maatalouden tapaturmien määrä on vähentynyt Suomessa viimeisen kymmenen vuoden aikana lähes 15 prosenttia samalla kuin tilojen määrä on vähentynyt, mutta maatalouskoneiden käyttöön liittyvien tapaturmien määrä ei ole vähentynyt vaan niiden osuus maatalouden tapaturmista on kasvanut viisi prosenttia. Eniten tapaturmia tapahtuu traktoreiden käytön ja huollon yhteydessä. Toisaalta traktoreita myös käytetään eniten maatiloilla. Työvaiheista koneiden huoltotehtävistä tapahtuu eniten tapaturmia ja erityisesti maatalouden sesonkityöaikoina keväisin ja syksyisin. Yli kolmannes maatalouden konetapaturmista on ns. vakavia tapaturmia, joissa tapaturman uhrille on määrätty yli kuukausi sairaslomaa. Keskimääräinen korvaussumma maatalouden konetapaturmissa on noin 3800 euroa per tapaturma.

Koneturva- hankkeessa tehdyn maatalouskoneiden käyttäjäkyselyn mukaan vastaajat pitivät koneiden käyttöönotto-opastusta, koneiden huollon helpottamista ja käyttöohjeiden kehittämistä tärkeimpinä työturvallisuusriskien hallintakeinoina. Merkittävä tekijä konetapaturmien ehkäisyssä on maatilan turvallisuuskulttuuri. Lähes puolet kyselyyn vastaajista oli sitä mieltä, että asennekasvatuksessa maatalouskoneiden käytön turvallisuusasioita kohtaan olisi parantamisen varaa. Yleisesti ottaen maatalouskoneita pidetään turvallisina ja koneiden käyttöohjeet olivat ymmärrettäviä noin 74 prosentin vastaajan mielestä. Maatalouskoneiden automaatiojärjestelmät ovat yleistyneet 
maatiloilla ja niihin liittyvää työturvallisuutta ja tapaturmia ei ole aikaisemmin tutkittu laajamittaisesti. Yli 30 prosenttia kyselyyn vastanneista maatalouskoneiden käyttäjistä piti koneiden automaatiojärjestelmiä vaikeina. Lisäksi automaatiojärjestelmien palaute-, neuvonta- ja ohjelmistopäivityspalveluita tulisi kehittää. Hankkeen tuloksena julkaistaan koneturvallisuusopas vuonna 2016.

\section{Kirjallisuus}

Eskola, E. 2012. Maatalouden konetöiden riskit. Maatalouskoneiden turvallisuus ja riskienhallinta - seminaari. PP-esitys. MTT/KoneAgria. 11.10.2013, Jyväskylä.

Laki 738/2002. Työturvallisuuslaki. Julkaistu internetissä: http://www.finlex.fi/fi/laki/ajantasa/2002/20020738.

Leppälä, J., Nysand, M., Ronkainen, A. ja Rautiainen, R. 2014. Koneiden korjaus aiheuttaa eniten maatalouskonetapaturmia. MTT:n Uutiskirje 17.12.2014.

Leppälä, J., Lätti, M., Smeds, P., Väre, M. (Eds.) 2013. Työvoiman ja työmäärän hallinta maatalousyrittäjän jaksamisen ja hyvinvoinnin turvaajina. MTT Raportti 117: $77 \mathrm{p}$

Malm, T., Hietikko, M., Tiusanen, R., Ronkainen, A. 2013. Safe performance of automated mobile work machines. In: Automation and Systems without Borders - beyond Future. Publication series of FSA 42: $6 \mathrm{~s}$.

Mayton, A., Kittusamy, N., Ambrose, D., Jobes, C. and Legault, M. 2007. Jarring/jolting exposure and musculoskeletal symptoms among farm equipment operators. International Journal of Industrial Ergonomics. Vol 38, 9-10, pp. 758-766.

Mela. 2014. Mata-vahingot. http://asp.hci.fi/mela/tilastot. Maatalousyrittäjien eläkelaitos. Espoo.

Ronkainen, A. 2013. Turvallisuus maatalouskoneiden automaatiojärjestelmissä. Maatalouskoneiden turvallisuus ja riskienhallinta - seminaari. PP-esitys. MTT/KoneAgria. 11.10.2013, Jyväskylä.,

Ronkainen, A. 2011. Fitness for use of ISOBUS network in safety-critical functions. In: XXXIV CIOSTA CIGR V Conference 2011 : Efficient and safe production processes in sustainable agriculture and forestry / Quendler E. and Kössler K. (Editors). BOKU. [p. 1-8].

Ronkainen, A. 2010. Safety of autonomous agricultural tractor-implement combinations with ISOBUS capabilities. MTT Raportti 6: $87 \mathrm{~s}$.

SFS-EN ISO 12100. 2010. Koneturvallisuus. Yleiset suunnitteluperiaatteet, riskin arviointi ja riskin pienentäminen.

Suutarinen, J., Nysand, M. \& Hänninen, M. 1998 "Maatalous- ja metsäalan koneiden ja laitteiden arviointi ja priorisointi markkinavalvonnan kohteina". Työsuojelujulkaisuja No 15. Sosiaali- ja terveysministeriö.

Suutarinen, J. 1996. Konetöiden turvallisuuden ja tehokkuuden parantaminen. VAKOLAn tutkimusselostus 75. MTT. Vihti. $40 \mathrm{~s}$.

Teye, F., Manni, J., Olkinuora, P. 2004. Benefits of agricultural and forestry machinery standardization in Finland. Agrifood Research Working Papers 78: 93 s. +5 liitettä.

TTL. 2013. Maataloustyöhön liittyvät tuki- ja liikuntaelinsairaudet. Työterveyslaitos. www.ttl.fi.

Vna 403/2008. Valtioneuvoston asetus työvälineiden turvallisesta käytöstä ja tarkastamisesta. Finlex.

2006/42/EY. EUROOPAN PARLAMENTIN JA NEUVOSTON DIREKTIIVI, annettu 17 päivänä toukokuuta 2006, koneista ja direktiivin 95/16/EY muuttamisesta (uudelleenlaadittu) 2006/42/EY. 